\title{
Juxta-articular myxoma of the temporomandibular joint: Case report and review
}

\author{
Elisabeth Goetze ${ }^{1 *}$, Abbas Agaimy ${ }^{2}$ and Marco Kesting ${ }^{1}$ \\ ${ }^{1}$ Department of Oral and Maxillofacial Surgery, Friedrich-Alexander University Erlangen-Nuremberg/ University Hospital Erlangen, Germany \\ ${ }^{2}$ Institute of Pathology, Friedrich-Alexander University Erlangen-Nuremberg/ University Hospital Erlangen, Germany
}

\begin{abstract}
Introduction: Juxta-articular myxoma (JAM) is a rare benign myxoid lesion that arises predominantly in the vicinity of large joints (hence the name) with the knee joint followed much less frequently by shoulder, elbow, hip and ankle joints being the main sites affected. Involvement of the temporomandibular joint (TMJ) by JAM is exceptionally rare making this entity not well-known by oro-maxillofacial surgeons. We present a case of JAM located at the TMJ and gives a systematic review of the literature on this topic.

Methods: A systematic search for "juxta-articular myxoma” “+"TMJ”, ”mandible” and temporomandibular” in English/French/German literature in PubMed, Medline, WebOfScience, OpenGrey and GoogleScholar was performed. The retrieved papers were then analyzed for the anatomical region, diagnostics, treatment, follow-up time and potential recurrence.

Results: JAM mainly occurs at the knee, shoulder or the elbow, other locations are rare. Main diagnostic imaging for JAM is MRI-scan. Excision of the lesion is standard therapy. Local recurrence is reported in $23 \%$ for an average follow-up of 38 months. Involvement of the TMJ was reported in $1 \%$ of total cases.

Conclusion: JAM is a rare benign tumor with local aggressive features. Occurrence at the mandible is quite rare. Due to the confined anatomical region of the TMJ complete removal may be difficult, a distinctive approach should be planned to guarantee optimal access. This fact and a high recurrence rate imply the need of a close follow-up.
\end{abstract}

\section{Introduction}

\section{Rationale - objectives}

Myxomas are benign tumors originating from mesenchymal cells and characterized by undifferentiated fibroblast-like mesenchymal cells embedded within abundant mucopolysaccharide-rich hypovascular myxoid stroma. Most cases originate in the skin and subcutaneous tissue or within skeletal muscle as intramuscular myxomas. The latter are characterized by recurrent GNAS mutations. On the other hand, juxta-articular myxomas (JAM) are much rare than intramuscular myxomas, lack GNAS mutations and are predominantly located in the vicinity of large joints, mainly the knee. Other sites such as the elbow, shoulder, hip and ankle joints are less frequently affected while involvement of the temporomandibular joint (TMJ) is very rare with only one case reported to date $[1,2]$.

In the orofacial area, myxomas are not uncommon and mostly occur in the gnathic skeleton of the odontogenic ectomesenchyme and are very similar to mesenchymal portions of a developing tooth [3]. Odontogenic myxomas are the most common myxomas arising from hard tissue, extragnathic skeletal myxomas are very rare [4].

In contrast, soft-tissue-type myxoid tumors (intramuscular myxoma, juxta-articular myxoma, superficial acral myxoma, superficial angiomyxoma and neural-sheat myxomas) usually do not or only rarely affect the orofacial region $[1,5]$. In regard to myxoid soft tissue tumors, intramuscular myxoma is the most common differential diagnosis for JAM. JAM differs from intramuscular myxoma by localization adjacent to a regularly arthrotic joint and infiltrative growing pattern, often with lobules [1]. Additionally, JAM does not show GNAS mutations in contrast to the intramuscular myxoma [6]. Other differential diagnoses are ganglion cysts, synovial cysts, intraarticular myxoma with extension to extraarticular regions and myxoid liposarcoma $[7,8]$.

Clinical presentation may be swelling in combination with pain under function or tenderness of the joint, even though JAM may just be an incidental finding [8]. Patients presenting with a JAM have an average age of 43 years, with a wide range of age as occurrence begin possible in young children, as well as in elderly patients $[7,9,10]$. JAM in temporomandibular joint has only been described in older people ( $>57$ years) so far.

\section{Case report}

A 60-year-old patient was referred to the department of oromaxillofacial surgery with a mass anterior to the left temporomandibular joint (TMJ). The mass was an accidental finding in a magnetic resonance tomography performed for the diagnosis of a tinnitus on both ears.

General patient's history revealed a mild hyperlipidemia and recurrent depressive syndrome, as well as an allergy to seafood.

${ }^{\star}$ Correspondence to: Elisabeth Goetze, Department of Oral and Maxillofacial Surgery, Friedrich-Alexander University Erlangen-Nuremberg/ University Hospital Erlangen, Glueckstr. 11, 91054 Erlangen, Germany, E-mail: Elisabeth. Goetze@uk-erlangen.de

Received: February 10, 2021; Accepted: February 23, 2021; Published: February 26,2021 
The patient had no symptoms associated with TMJ pathology so far. Mouth opening was unrestricted with a $46 \mathrm{~mm}$, no mandible deviation occurred during mouth opening, no malocclusion, no facial palsy or alternation of trigeminal sensitivity were present. A slight click could sometimes be detected over the TMJ of the contralateral side.

Panoramic X-ray was rendered by the dentist and showed no destruction of the TMJ region (Figure 1 and 2). CT and MR scans sent by the referring ENT showed a mass of $20 \times 15 \times 12 \mathrm{~mm}$ size.

In detail, CT showed a partially eroded mandibular condyle with an adjunct lesion with borderline contrast agent uptake and a central hypodense region with a size of about $2.1 \times 1.9 \mathrm{~cm}$. MR showed a partially cystic lesion within the pterygoidal muscles anterior to the left mandible condyle (Figure 3 a-d).

For histopathologic evaluation of the lesion surgical removal was scheduled. Following the patient's informed consent, the procedure was performed under general anaesthesia.

The TMJ was exposed through a preauricular approach and a temporary osteotomy of the zygomatic arch was conducted for better access. After blunt preparation through the pterygoid muscle the lesion presented as a fibrous mass of approximately $2 \mathrm{~cm}$ diameter with adhesion to the TMJ joint capsule. A capsule surrounding the lesion was not present (Figure 4a-b). The lesion was excised, therefore it had to be sharply dissected from the joint capsule. The zygomatic arch was repositioned and retained through an osteosynthesis plate. Postoperative facial motor function was uncompromised.

Histopathological evaluation showed a mesenchymal tumor with low cellularity and highly myxoid stroma. Fibroblast-like and histiocytoid cell elements with hyperchromatic nuclei and slightly eosinophilic cytoplasm were embedded within hypovascular stroma with variable pseudocystic degeneration. Vascularization was sparse and there were no atypia or mitoses (Figure $5 \mathrm{a}$ and $5 \mathrm{~b}$ ).
Immunohistochemically the tumor showed no positivity for S100, CD34 or MUC4. The histological profile was in accordance with a juxta-articular myxoma.

The patient recovered fully without any complications. Functional outcome of the temporomandibular joint showed no restrains. Followup of 8 month has not shown any sign of recurrence so far.

\section{Methods}

The systematic review was done according to the STARLITEstatement. An electronic research was conducted in PubMed, Web Of Science and Medline, additionally grey literature was also searched via Google Scholar and OpenGrey. The search timeframe ranged from 1970-2020. Last access date was 6th of January 2021.

Literature research was limited to English, French and German references. Only literature dealing with human subjects was eligible. Case reports, case series, systematic reviews were included.

Keywords used were "juxta-articular myxoma", "juxtaarticular myxoma", "juxta-articular myxoma" + "TMJ", "juxta-articular myxoma" + "mandible", "Myxoma" + "temporomandibular". In addition to the keyword results the option "Related articles" was used, and citations of the eligible articles were checked.

Search results were scanned by abstract. If the abstract covered the subject of juxta-articular myxoma full-text was retrieved and assessed. In case of missing abstracts fulltext was assessed first-hand. Literature was tabulated in an Excel file. Doubles were deleted. Narrative reviews without case presentation or retrospective analysis of a population were excluded.

The full-texts were scanned for diagnosis of juxta-articular myxoma, diagnostic imaging, anatomical region of the lesion, therapy, recurrence and follow-up time. A summary of the search strategy is seen in Table 1.

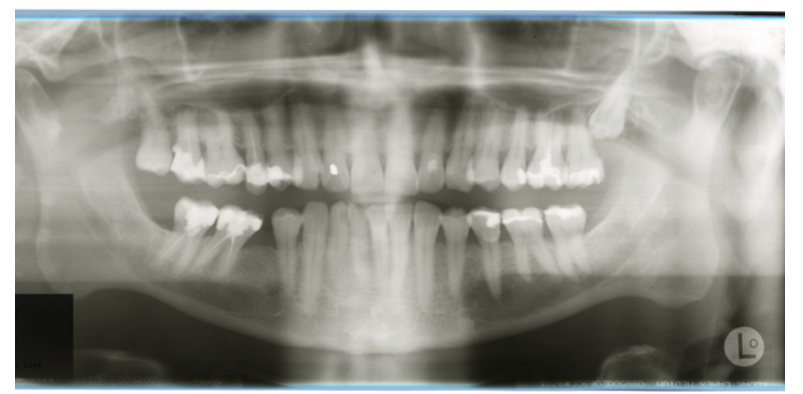

Figure 1. Panoramic X-ray: the X-ray shows no sign of erosion or pathologic mass in the region of the left temporomandibular joint

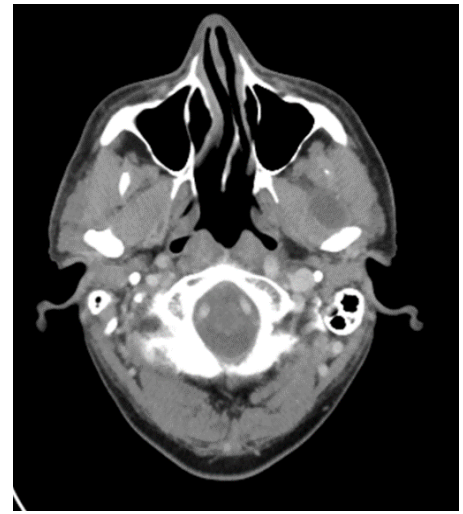

Figure 2. Preoperative computer tomography with a hypodense lesion with circular borderline uptake of contrast agent anterior to the left temporomandibular joint 

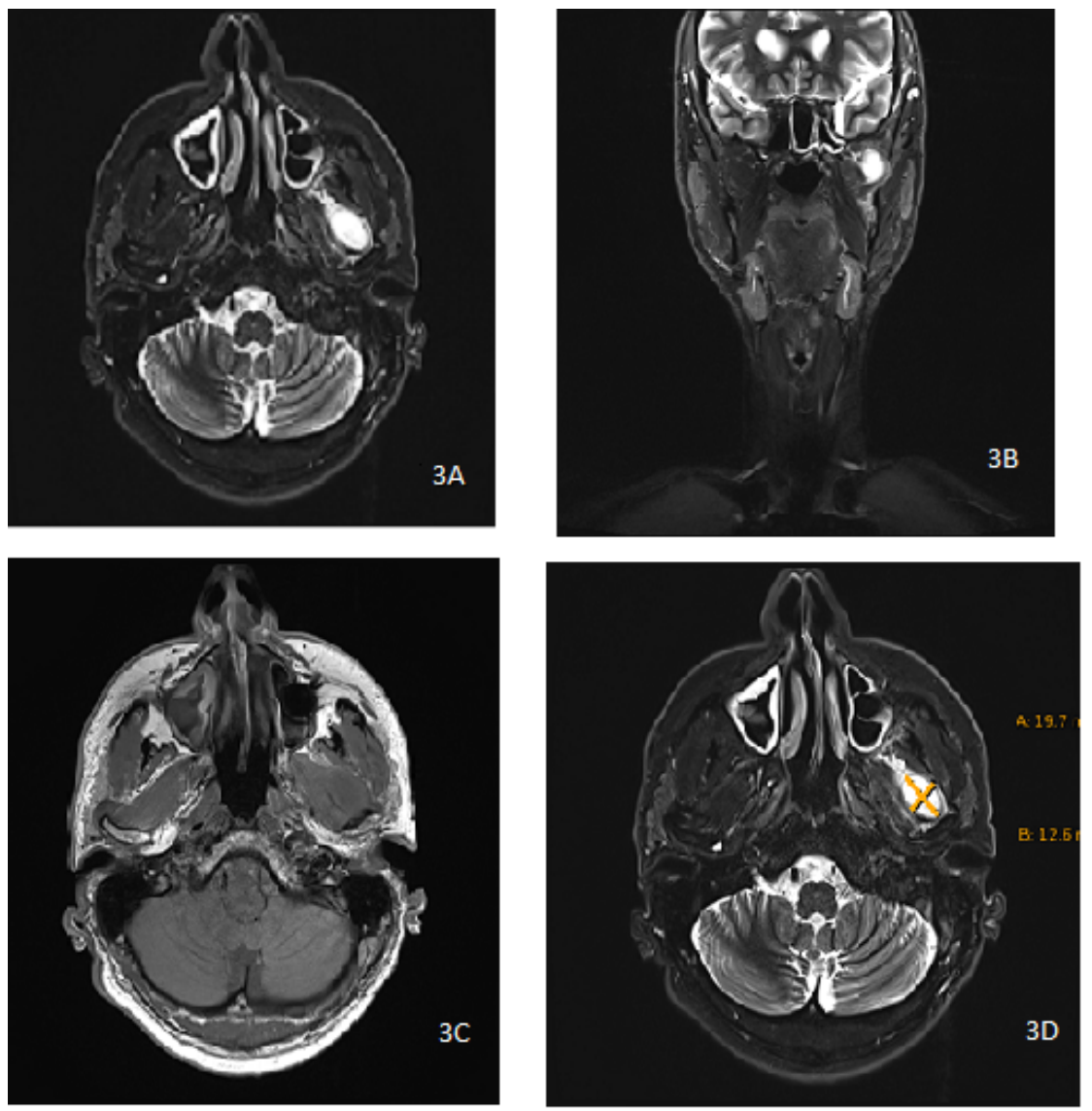

Figure 3. Preoperative magnet resonance tomography with hyperintense lesion anterior to the temporomandibular joint left
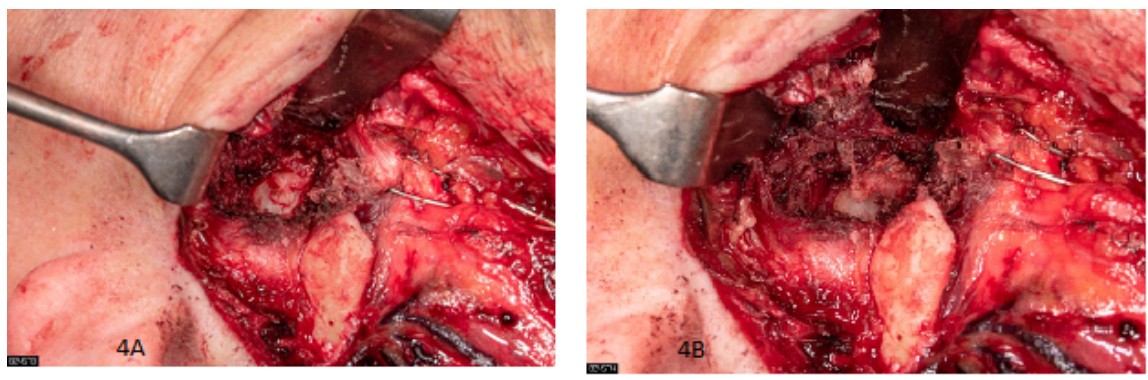

Figure 4. Intraoperative presentation of a fibrous lesion adjacent to the capsule of the temporomandibular joint
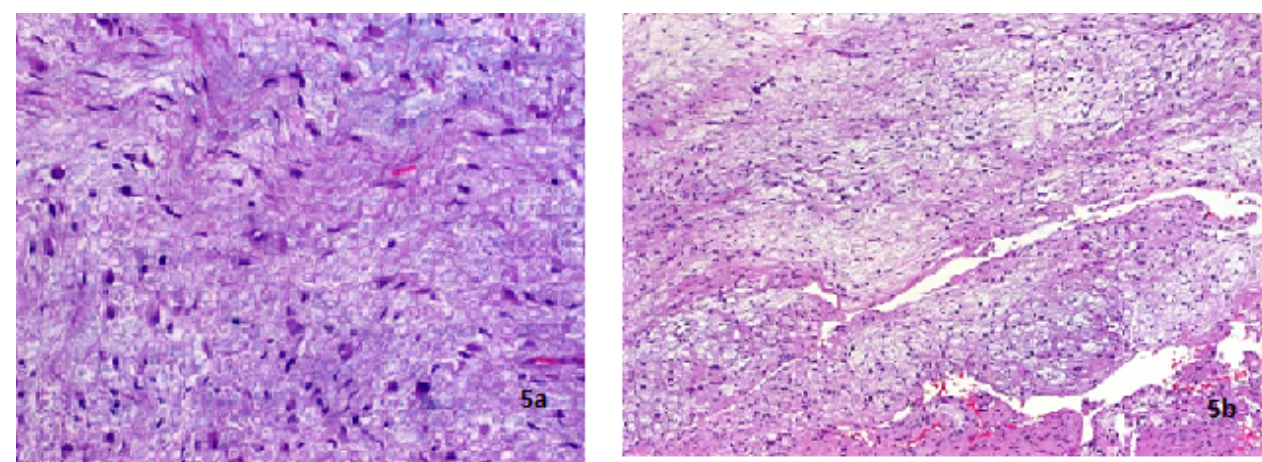

Figure 5. 5a - at low power, JAM shows low cellularity with highly myxoid hypovascular stroma and variable focal cystic degeneration; $5 \mathrm{~b}$ - at high power, mononculear spindled, fusiform and stellate cells with minimal atypia are seen 


\section{Results}

Primary search retrieved 110 articles in PubMed and 588 hits in GoogleScholar. There were no results by OpenGrey. MedLine retrieved 17 results and WebOfScience 12 results. Articles eligible for full-text assessment were 27 - 21 in PubMed/Medline/Web Of Science and additional 6 in Google Scholar after removal of doubles. Literature check through "Related Articles" respectively, "Similar Articles" or of the citations (snowballing) brought no additional results.

The results for full-text assessment consisted of 19 case reports, 2 case reports in combination with a review and 3 case series, which enclosed one retrospective clinical case series and two retrospective cyto-pathological case series. Three reviews had to be excluded for the lack of case presentation or analysis of a population. Finally, 24 articles were eligible for analysis (Table 2).
The overall number of cases diagnosed as JAM was $n=92$. Locations for JAM were predominantly knee $(n=69)$, followed by shoulder $(n=5)$ and elbow $(n=4)$. More rarely, JAM was reported for hip $(n=3)$, wrist $(n=3)$, hand $(n=3)$, at the spine $(n=2)$, ankle $(n=1)$, foot $(n=1)$ or the temporomandibular joint $(\mathrm{n}=1 ; 1 \%)$.

Regarding diagnostic imaging 3/24 articles have not provided any information regarding imaging procedures. The two cyto-pathological case series and one case-report have not included any information about medical imaging either.

MR was performed as diagnostic imaging in 18/24 articles, in $7 / 18$ articles in combination with conventional $x$-ray, $3 / 18$ in combination with ultrasound and $1 / 18$ articles in combination with CT-scans. Conventional X-ray was used in $8 / 24$ publications, either in combination with MR (7/8) or ultrasound (1/8). In two publications

Table 1. Review criteria after STARLITE-statement

\begin{tabular}{|c|l|}
\hline STARLITE & \\
\hline Sampling strategy & Abstracts > full text \\
\hline Type of study & case reports, case series, RCT, systematic review, meta-analysis \\
\hline approaches & keyword search, Citations (snowballing), Option: "related articles"/similar articles" \\
\hline range of years & $1970-2020$, last search 6.1.2021 \\
\hline limits & Language: English, French and German, Subject: human \\
\hline inclusion/exclusion & $\begin{array}{l}\text { Included: subject of article is juxta-articular myxoma } \\
\text { Excluded: narrative review without case presentation or retrospective analysis of population }\end{array}$ \\
\hline terms used & $\begin{array}{l}\text { "juxta-articular myxoma" } \\
\text { "juxtaarticular myxoma" } \\
\text { "juxta-articular myxoma" + "TMJ" } \\
\text { "juxta-articular myxoma" + "mandible" } \\
\text { "Myxoma" + "temporomandibular" }\end{array}$ \\
\hline electronic sources & PubMed, Medline, Web of Science, Google Scholar, Open Grey \\
\hline
\end{tabular}

Table 2. Summary of search results in alphabetical order, $n=$ number of cases, $M R=$ magnet resonance tomography, $C T=$ computer tomography

\begin{tabular}{|c|c|c|c|c|c|c|c|c|c|c|c|c|c|}
\hline & Author & Year & Title & Source & language & $\begin{array}{l}\text { Type of } \\
\text { literature }\end{array}$ & $\begin{array}{c}\text { Number } \\
\text { of cases } \\
\text { (n) }\end{array}$ & $\begin{array}{c}\text { Anatomical } \\
\text { region }\end{array}$ & therapy & $\begin{array}{l}\text { Diagnostic } \\
\text { imaging }\end{array}$ & recurrence & $\begin{array}{c}\text { follow-up } \\
\text { time }\end{array}$ & Special \\
\hline 1 & $\begin{array}{l}\text { Sandhu, et } \\
\text { al. [11] }\end{array}$ & 2016 & $\begin{array}{c}\text { Juxta-articular } \\
\text { myxoma of the hand }\end{array}$ & PubMed & English & case report & 1 & palma & excision & MR & na & na & capsule \\
\hline 2 & $\begin{array}{c}\text { Raffaele, et } \\
\text { al. }[12]\end{array}$ & 2019 & $\begin{array}{l}\text { Juxta-articular } \\
\text { myxoma of the hip: a } \\
\text { rare pediatric tumor }\end{array}$ & PubMed & English & case report & 1 & hip & excision & $\begin{array}{c}\text { radiographs, } \\
\text { ultrasound, } \\
\mathrm{mr}\end{array}$ & no & $30 \mathrm{mo}$ & capsule \\
\hline 3 & $\begin{array}{c}\text { Irving, et al. } \\
{[13]}\end{array}$ & 2012 & $\begin{array}{c}\text { Juxta-articular } \\
\text { myxoma of the palm }\end{array}$ & PubMed & English & case report & 1 & palma & excision & $\mathrm{mr}$ & no & $12 \mathrm{mo}$ & \\
\hline 4 & $\begin{array}{l}\text { Ye, et al. } \\
\text { [14] }\end{array}$ & 2015 & $\begin{array}{c}\text { Juxta-articular } \\
\text { myxoma of the } \\
\text { temporomandibular } \\
\text { joint }\end{array}$ & PubMed & English & case report & 1 & tmj & excision & $\mathrm{CT}, \mathrm{MR}$ & no & $30 \mathrm{mo}$ & \\
\hline 5 & $\begin{array}{l}\text { Daluiski, et } \\
\text { al. }[15]\end{array}$ & 1995 & $\begin{array}{l}\text { A case of juxta- } \\
\text { articular myxoma of } \\
\text { the knee }\end{array}$ & PubMed & English & case report & 1 & knee & excision & $\begin{array}{c}\text { radiographs, } \\
\mathrm{mr}\end{array}$ & na & na & \\
\hline 6 & $\begin{array}{c}\text { Körver, et } \\
\text { al. [7] }\end{array}$ & 2010 & $\begin{array}{c}\text { Juxta-articular } \\
\text { Myxoma of the } \\
\text { Knee in a 5-year-old } \\
\text { Boy: A Case Report } \\
\text { and Review of the } \\
\text { Literature }\end{array}$ & PubMed & English & $\begin{array}{l}\text { review/case } \\
\text { report }\end{array}$ & 1 & knee & excision & $\begin{array}{c}\text { radiographs, } \\
\mathrm{mr}\end{array}$ & no & $10 \mathrm{mo}$ & \\
\hline 7 & $\begin{array}{c}\text { Somford, et } \\
\text { al. [16] }\end{array}$ & 2011 & $\begin{array}{c}\text { Juxta-articular } \\
\text { Myxoma of the knee }\end{array}$ & PubMed & English & case report & 1 & knee & excision & $\mathrm{mr}$ & na & na & \\
\hline 8 & $\begin{array}{c}\text { Okamoto, et } \\
\text { al. [6] }\end{array}$ & 2002 & $\begin{array}{l}\text { Juxta-articular } \\
\text { myxoma and } \\
\text { intramuscular } \\
\text { myxoma are } 2 \\
\text { distinct entities }\end{array}$ & PubMed & English & $\begin{array}{c}\text { case series (histo- } \\
\text { pathology) }\end{array}$ & 5 & 4 knee, 1 foot & excision & na & no & $\begin{array}{c}2,5-5 \mathrm{y}, \\
\operatorname{MD} 36 \mathrm{mo}\end{array}$ & \\
\hline 9 & $\begin{array}{l}\text { Claudi, et } \\
\text { al. }[17]\end{array}$ & 2020 & $\begin{array}{l}\text { A juxta-articular } \\
\text { myxoma of the } \\
\text { thumb a case report }\end{array}$ & PubMed & English & case report & 1 & hand & excision & $\mathrm{mr}$, ultrasound & no & $8 \mathrm{mo}$ & \\
\hline
\end{tabular}




\begin{tabular}{|c|c|c|c|c|c|c|c|c|c|c|c|c|c|}
\hline 10 & $\begin{array}{c}\text { Yan, et al. } \\
\text { [18] }\end{array}$ & 2016 & $\begin{array}{c}\text { Fibular juxta-articular } \\
\text { ganglion: a rare case } \\
\text { report and literature } \\
\text { review }\end{array}$ & PubMed & English & $\begin{array}{l}\text { review/case } \\
\text { report }\end{array}$ & 1 & knee/fibula & excision & $\mathrm{x}$-ray, mr & no & $6 \mathrm{mo}$ & intraosseous \\
\hline 11 & $\begin{array}{c}\text { Abkari, et } \\
\text { al. [19] }\end{array}$ & 2010 & $\begin{array}{c}\text { Juxta articular } \\
\text { myxoma of the wrist: } \\
\text { a case report }\end{array}$ & PubMed & French & case report & 1 & wrist & excision & $\begin{array}{l}\text { ultrasound, } \\
\text { wrist } 2 \text { planes }\end{array}$ & no & $4 \mathrm{mo}$ & \\
\hline 12 & $\begin{array}{c}\text { Beggan, et } \\
\text { al. }[20]\end{array}$ & 2014 & \begin{tabular}{|c|} 
Juxta-articular \\
myxoma: an \\
unusual benign \\
mesenchymal lesion, \\
readily mistaken for \\
malignancy
\end{tabular} & PubMed & English & case report & 1 & spine & excision & MR & na & na & \\
\hline 13 & $\begin{array}{l}\text { Ozcanli, et } \\
\text { al. }[21]\end{array}$ & 2005 & $\begin{array}{c}\text { Juxta-articular } \\
\text { myxoma of the wrist: } \\
\text { a case report }\end{array}$ & PubMed & English & case report & 1 & wrist & excision & & no & $12 \mathrm{mo}$ & \\
\hline 14 & $\begin{array}{c}\text { Meis, et al. } \\
\text { [8] }\end{array}$ & 1992 & \begin{tabular}{|c|} 
Juxta-articular \\
myxoma: a clinical \\
and pathologic study \\
of 65 cases
\end{tabular} & PubMed & English & $\begin{array}{l}\text { case series } \\
\text { (clinical) }\end{array}$ & 65 & $\begin{array}{c}57 \text { knee, } 3 \\
\text { shoulder, } 3 \\
\text { elbow, } 1 \text { hip, } \\
1 \text { ankle }\end{array}$ & excision & $\begin{array}{l}\text { radiographs, } \\
\text { arthroscopy }\end{array}$ & $34 \% 10 / 29$ & $\begin{array}{c}\text { for } 45 \% 2 \\
\text { mo - } 18 \text { y } \\
\text { average } 5,6 \\
\text { years }\end{array}$ & \\
\hline 15 & $\begin{array}{c}\text { Kosty, et al. } \\
\text { [22] }\end{array}$ & 2009 & $\begin{array}{l}\text { juxta-articular } \\
\text { myxoma within the } \\
\text { suprapatellar pouch } \\
\text { masquerading as a } \\
\text { ganglion cyst }\end{array}$ & PubMed & English & case report & 1 & knee & excision & $\begin{array}{c}\mathrm{mr}, \\
\text { arthroscopie }\end{array}$ & na & na & only abstract \\
\hline 16 & $\begin{array}{l}\text { Minkoff, et } \\
\text { al. [23] }\end{array}$ & 2003 & \begin{tabular}{|c|} 
juxta-articular \\
myxoma: a rare cause \\
of painful restricted \\
motion of the knee
\end{tabular} & PubMed & English & case report & 1 & knee & excision & $\mathrm{mr}$ & no & $12 \mathrm{mo}$ & \\
\hline 17 & $\begin{array}{l}\text { Wakely jr, } \\
\text { et al. }[24]\end{array}$ & 2005 & $\begin{array}{c}\text { The cytopathology } \\
\text { of soft tissue } \\
\text { mxyomas: ganglia, } \\
\text { juxta-articular } \\
\text { myxoid lesions, } \\
\text { and intramuscular } \\
\text { myxoma }\end{array}$ & PubMed & English & $\begin{array}{c}\text { case series } \\
\text { (cytopathology) }\end{array}$ & 1 & hip & excision & na & na & na & \\
\hline 18 & $\begin{array}{c}\text { Echols, et } \\
\text { al. }[25]\end{array}$ & 2000 & $\begin{array}{l}\text { Juxta-articular } \\
\text { myxoma of the } \\
\text { shoulder presenting } \\
\text { as a cyst of the } \\
\text { acromioclavicular } \\
\text { joint: a case report }\end{array}$ & PubMed & English & case report & 1 & shoulder & excision & $\mathrm{mr}$ & no & $48 \mathrm{mo}$ & \\
\hline 19 & $\begin{array}{l}\text { Sciot, et al. } \\
\text { [26] }\end{array}$ & 1999 & $\begin{array}{l}\text { Clonal chromosomal } \\
\text { changes in juxta- } \\
\text { articular myxoma }\end{array}$ & PubMed & English & case report & 1 & elbow & excision & $\mathrm{mr}$ & no & 9 mo & $\begin{array}{c}\text { chromosomal } \\
\text { changes }\end{array}$ \\
\hline 20 & $\begin{array}{l}\text { King, et al. } \\
{[27]}\end{array}$ & 1995 & $\begin{array}{l}\text { Magnetic resonance } \\
\text { imaging of juxta- } \\
\text { articular myxoma }\end{array}$ & PubMed & English & case report & 1 & knee & excision & $\begin{array}{c}\underset{\mathrm{mr}}{\text { radiographs, }} \\
\mathrm{mr}\end{array}$ & na & na & \\
\hline 21 & $\begin{array}{c}\text { Van den } \\
\text { Heever [28] }\end{array}$ & 2014 & $\begin{array}{c}\text { Juxta-articular } \\
\text { myxoma of the wrist: } \\
\text { a case report }\end{array}$ & $\begin{array}{l}\text { Google } \\
\text { scholar }\end{array}$ & English & case report & 1 & wrist & excision & $\mathrm{mr}$ & yes & after $4 \mathrm{mo}$ & \\
\hline 22 & $\begin{array}{l}\text { Boussakri, } \\
\text { et al. }[29]\end{array}$ & 2016 & $\begin{array}{c}\text { Juxta-articular } \\
\text { myxoma of the knee } \\
\text { joint }\end{array}$ & $\begin{array}{l}\text { Google } \\
\text { scholar }\end{array}$ & English & case report & 1 & knee & excision & $\begin{array}{l}\text { ultrasound, } \\
\text { radiographs, } \\
\mathrm{mr}\end{array}$ & & na & na \\
\hline 23 & Popp [10] & 2015 & $\begin{array}{c}\text { Juxta-articular } \\
\text { myxoma of the } \\
\text { shoulder in a } 85 \text {-year- } \\
\text { old female: a case } \\
\text { report and literature } \\
\text { review }\end{array}$ & $\begin{array}{l}\text { Google } \\
\text { scholar }\end{array}$ & English & case report & 1 & shoulder & excision & ct & na & na & abstract book \\
\hline 24 & $\begin{array}{c}\text { Eliyas, et al. } \\
\text { [30] }\end{array}$ & 2017 & $\begin{array}{c}\text { Juxta-articular } \\
\text { myxoma arising from } \\
\text { a lumbar facet joint }\end{array}$ & $\begin{array}{l}\text { Google } \\
\text { scholar }\end{array}$ & English & case report & 1 & spine & excision & $\mathrm{mr}$ & no & na & only abstractt \\
\hline
\end{tabular}


ultrasound, radiographs and MR were combined (2/24). Arthroscopy was used in 2 cases for diagnostics, once in combination with MR $(1 / 24)$, once in combination with radiographs $(1 / 24)$. One paper used solely CT for diagnostics (1/24).

92/92 of JAM were treated through excision. Follow-up data was missing for 45 patients (49\%). Recurrence has been reported for 11 of the 47 cases available for follow-up (23\%). Follow-up time ranged from 2 months to 18 years, average follow-up-time was 38 months.

\section{Discussion}

Juxta-articular myxoma is a rare benign lesion usually presenting at the large joint. These lesions regularly are incidental findings [8-30] and rarely cause clinical problems. Presence of a juxta-articular myxoma is even more uncommon in the temporo-mandibular joint (TMJ), hence this entity has mostly been unknown to the oro-maxillofacial surgeon.

There is no substantial information available regarding standard diagnostics in case of a juxta-articular myxoma. Magnetic resonance seems to be regularly applied, often in combination with regular X-rays [27].

Regular treatment for the juxta-articular myxoma is radical surgical removal [14]. In case of the TMJ this may be quite complicated due to the confined space and the proximity to the facial nerve [14]. Transzygomatical, transcondylar or transcoronoid approaches with temporary osteotomy of occluding bones are common methods for procedures at the temporomandibular joint and allow controlled though still narrow accessible space. If these facts possibly result in an increased recurrence rate, is up to discussion. The substantial lack of cases does not allow a valid estimation of effects. There may be a relation to degenerative altered joints for JAM [1] which may contribute to recurrence, as well.

In contrast to skeletal myxomas regularly situated in the gnathic system JAM does not infiltrate the bone but may cause local erosion. Hence, ablative surgery of the temporomandibular joint is not necessary for the treatment of JAM.

The surgical approach through temporary osteotomy of the zygomatic arch in the case described here, allowed sufficient access to the pterygoid fossa, and complete removal was possible in medial and medio-anterior direction. Partial removal of the joint capsule and distinctive reconstruction through fascial duplication allowed perseverance of the joint. So far, the surgical technique has seemingly been suitable for the management of JAM at the temporomandibular joint with a good outcome in function and disease-free survival.

The overall prognosis for a juxta-articular myxoma seems to be good regarding the functional outcome, even though the risk of recurrence is quite high with $23-34 \%$ reported in literature and the performed review. Malignant transformation is not described for JAM. Recurrence may occur after several years [8]. The possibility of recurrence and local aggressive expansion with erosion of surrounding articular bone suggests a close follow-up to treat recurrence in early stages and maintain function as far as possible.

\section{References}

1. Agaimy A (2019) Myxoid soft tissue tumours: An algorithm for differential diagnosis. Pathologe 40: 353-365. [Crossref]

2. Cinza A, Monje F, Fernandez de Mera JJ (2019) A myxoma in the temporomandibular joint: Case report and review of the literature. Oral Oncol 88: 16-17. [Crossref]
3. Neville D, Bouquot A. Oral \& Maxillofacial Pathology. 3rd ed. 2009, Philadelphia: Sounders.

4. Santhanam SS, Goni V, Saibaba B, Das A (2015) Myxoma of the femur: an unusual site of origin. BMJ Case Rep 2015: bcr2015211480. [Crossref]

5. OC J, N G (2002) Benign Myxoid Fibroblastic Tumors of Soft Tissue: The Myxomas Pathology Case Reviews 7: 146-152.

6. Okamoto S, Hisaoka M, Meis-Kindblom JM, Kindblom LG, Hashimoto H (2002) Juxta-articular myxoma and intramuscular myxoma are two distinct entities. Activating Gs alpha mutation at Arg 201 codon does not occur in juxta-articular myxoma. Virchows Arch 440: 12-15. [Crossref]

7. Korver RJ, Theunissen PHMH, van de Kreeke WT, van der Linde MJA, Heyligers IC (2010) Juxta-articular myxoma of the knee in a 5-year-old boy: a case report and review of the literature (2009: 12b). Eur Radiol 20: 764-768. [Crossref]

8. Meis JM, Enzinger FM (1992) Juxta-articular myxoma: a clinical and pathologic study of 65 cases. Hum Pathol 23: 639-646. [Crossref]

9. Pathology and Genetics of Tumours of Soft Tissue and Bone. World Health Organisations of Classification of Tumours, ed. C. Fletcher, K. Krishnan Unni, and F. Mertens. 2002, Lyon: IARC Press.

10. Popp B, Chan S (2015) Juxta-articular myxoma of the shoulder in an 85-year-old female: a case report and literature review. Pathology 47: S72.

11. Sandhu SS, Elston JB, Harrington MA, Payne WG (2016) Juxta-articular Myxoma of the Hand. Eplasty 16: ic41. [Crossref]

12. Raffaele A, Goruppi I, Mosconi M, Pelillo F, Lucioni M, et al. (2019) Juxta-articular Myxoma of the Hip: A Rare Pediatric Tumor. J Am Acad Orthop Surg Glob Res Rev 3: e070. [Crossref]

13. Irving A, Gwynne-Jones D, Osipov V, Nicholson MI (2012) Juxta-articular myxoma of the palm. J Surg Case Rep 2012: 12. [Crossref]

14. Ye ZX, Yang C, Chen MJ, Wilson JJ (2015) Juxta-articular Myxoma of the Temporomandibular Joint. J Craniofac Surg 26: e695-e696. [Crossref]

15. Daluiski A, Seeger LL, Doberneck SA, Finerman GA, Eckardt JJ (1995) A case of juxta-articular myxoma of the knee. Skeletal Radiol 24: 389-391. [Crossref]

16. Somford MP, de Vries JS, Dingemans W, de Jonge M, Maas M, et al. (2011) Juxtaarticular myxoma of the knee. J Knee Surg 24: 299-301. [Crossref]

17. Claudi C, Andreisek G, Vrugt B, Ganser J (2020) A Juxta-Articular Myxoma of the Thumb A Case Report. J Hand Surg Glob Online 2: 171-174. [Crossref]

18. Yan X, Zhang Z, Lin N, Xie T, Ye Z (2016) Fibular juxta-articular ganglion: A rare case report and literature review. Mol Clin Oncol 5: 590-592. [Crossref]

19. Abkari I, Hassib JEI, Latifi M, Hazmiri FE, Belaabidia B (2010) Juxta articular myxoma of the wrist: a case report. Chir Main 29: 277-279. [Crossref]

20. Beggan C, Davies K, Leader M (2014) Juxta-articular myxoma: an unusual benign mesenchymal lesion, readily mistaken for malignancy. Ir Med $J$ 107: 212-213. [Crossref]

21. Ozcanli H, Ozenci AM, Gurer EI, Tuzuner S (2005) Juxta-articular myxoma of the wrist: a case report. J Hand Surg Am 30: 165-167. [Crossref]

22. Kosty JW, Moore JG (2009) Juxta-articular myxoma within the suprapatellar pouch masquerading as a ganglion cyst. Orthopedics 32: 527. [Crossref]

23. Minkoff J, Stecker S, Irizarry J, Whiteman M, Woodhouse S (2003) Juxta-articular myxoma: a rare cause of painful restricted motion of the knee. Arthroscopy 19: E6-13. [Crossref]

24. Wakely PE, Bos GD, Mayerson J (2005) The cytopathology of soft tissue mxyomas: ganglia, juxta-articular myxoid lesions, and intramuscular myxoma. Am J Clin Pathol 123: 858-865. [Crossref]

25. Echols PG, Omer GE, Crawford MK (2000) Juxta-articular myxoma of the shoulder presenting as a cyst of the acromioclavicular joint: a case report. J Shoulder Elbow Surg 9: 157-159. [Crossref]

26. Sciot R, Cin PD, Samson I, van den Berghe H, Van Damme B (1999) Clonal chromosomal changes in juxta-articular myxoma. Virchows Arch 434: 177-180. [Crossref]

27. King DG, Saifuddin A, Preston HV, Hardy GJ, Reeves BF (1995) Magnetic resonance imaging of juxta-articular myxoma. Skeletal Radiol 24: 145-147. [Crossref] 
Goetze E (2021) Juxta-articular myxoma of the temporomandibular joint: Case report and review

28. Van den Heever A (2014) Juxta- articular myxoma of the wrist S Afr J Rad 2: 668

29. Boussakri H, Elibrahimi A, Elmrini A (2016) Juxta-Articular Myxoma of the Knee Joint. SM J Orthop 2: 1035
30. Eliyas JK, Pytel P, Roitberg BZ (2017) Juxta Articular Myxoma arising from a lumbar facet joint. Edizioni Minerva Medica 30: 21-24.

Copyright: $\odot 2021$ Goetze E. This is an open-access article distributed under the terms of the Creative Commons Attribution License, which permits unrestricted use, distribution, and reproduction in any medium, provided the original author and source are credited. 